\title{
HD-ZIP Domain
}

National Cancer Institute

\section{Source}

National Cancer Institute. HD-ZIP Domain. NCI Thesaurus. Code C13636.

Bipartite DNA binding domain containing a homeo domain and a leucine zipper. 